Dept. of Animal Hygiene,

Faculty of Vet. Med., Assiut University,

Head of Dept. Prof. Dr. A.A. Ismail.

\title{
STUDY ON THE BACTERIOCIDAL EFFETIVENESE OF SOME DISINFECTANTS AND THE BIOLOGICAL VALUE OF FEEDLOT WASTES AND POULTRY LITTER AFTER BEING APPLIED
} (Wit 3 Tables)

By

\section{A.H. HAFEZ; F.A. AHMED; M.A. SOBEH and M.I. ABOZEID* (Received at 12/21/1988)}

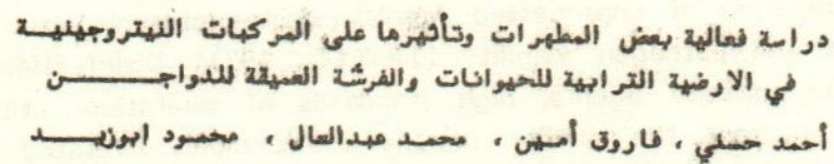

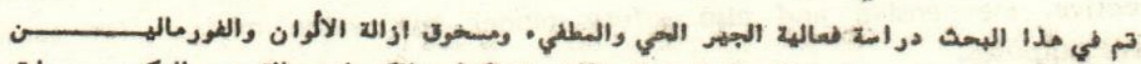



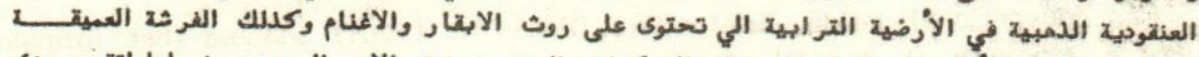

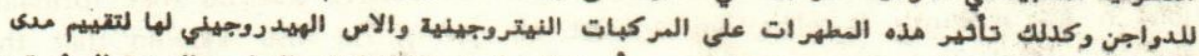

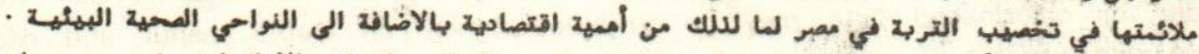

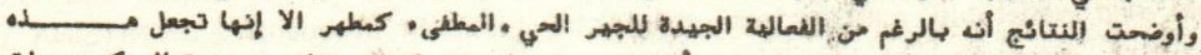

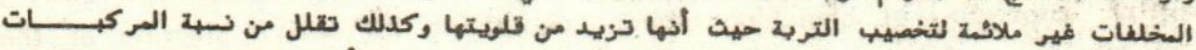

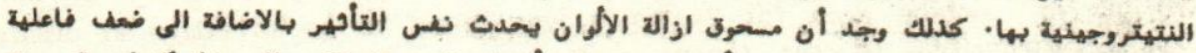



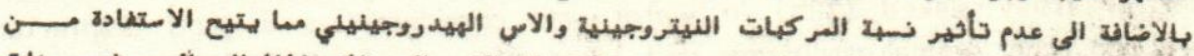



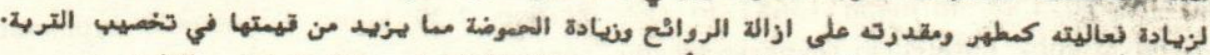

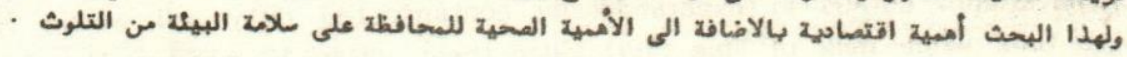

\section{SUMMARY}

The study dealed with the effectiveness of lime, chlorinated lime, formalin and superphosphate compound applied to cattle and sheep wastes combined with bedding and to poultry litter experimentally contaminated with Salmonella typhimurium, E.coli, corynbacterium pyogenes and Staphylococcus aureus. Moreover, the study investigate the effect of disinfectants used on the behnviour of some nitrogen compounds in the feedlot wastes and poultry litter.

Experimental results revealed that the bacteriocidal effectiveness of disinfectants used ranked in increasing order of expposure time as: Quick lime, saked lime, formalin, beleaching and superphosphate. Evaluation of wastes after disinfection revealed that lime and chlorinated lime decreased the contents of several nitrogen forms in animal and poultry

* : Soils and Water Dept. Fac. of Agric., Assiut University.

Assiut Vet.Med.J. Vol. 21, No. 42, 1989. 


\section{A.H. HAFEZ, et al.}

wastes as well as increased its alkalinity which decreased its value for utilization on to lands and can be a problem in some crops. In contrast, formalin $4 \%$ as well as superphosphate increases in nitrogen contents of the wastes and $\mathrm{pH}$ ranged from neutral to acidic respectively and therefore such management could be more suitable to Egyptian soils.

\section{INTRODUCTION}

Most infected animals or birds eliminate the pathogenic agents by way of urine, faeces or droppings so that germs ultimately come into contact with the floor of the buildings. Utilization of unprocessed feedlot wastes presents problems of zoonosis, aethetic problems and pathogen viabllity (TAYLOR, 1971). Disinfection is an important part of controlling disease agents, high standards of sanitation, utilization of waste products and to protect the quality of the environment. Prefered disinfectants are the effective, inexpensive and also safety render the waste mixture for subsequent agriculture purposes.

For conventional inside disinfection, DYKSTRA (1961) showed that formaldehyde solution in $4 \%$ strength is effective against all germs. He also showed that the dry powder of chlorinated lime may be sprinkled lightly on stable manur and decaying animal and vegetable matters and should be repeated frequently. GRINITSINA (1964) found that suspension of bleaching powder containing $2 \%$ active chlorine at the rate of $1 \mathrm{~L}$ per $\mathrm{m}^{2}$ surface area for 24 hours was found to be effective in disinfecting farm yerds. KRASNOSHCHEKOV (1962) reported that quick lime scattered as a dry powder of frshly slaked (20\%) in water was considered as a good disinfectant on manure and other animal discharges that killed microorganisms within 5 minutes. ISMAIL (1967) showed that formalin (36\%) in the dilution 1:30 killed Salmonella typhimurium, E.coli and Staph. aureus in experimentally contaminated dirty soil within 30 minutes exposure time while milk of lime (1:4) killed them within 10 minutes. He also reported that suspension of bleaching powder in water containing $0.06 \%$ active chlorine killed Salmonella typhimurium and E.coli after 20 minutes but Staph. aureus after $1 \mathrm{~h}$. exposure.

On the other hand, DYKSTRA (1961) showed that when superphosphate compound was added from time to time to manure accumulations, it serves as a deodorant and fix ammonia nitrogen so as prevent its escape and thus leaves the manure as a more valuable fertilizer. He stated that litter used in poultry houses are placed on the floor to a depth of six inches and mixed with hydrated lime or superphosphate at a rate 25 pounds for each 400 square feet of floor space. Moreover, YOVCHEV (1974) revealed that Salmonella abortus ovis could not be recovered from soiled litter of a lambing pen after treatment with bleaching powder $200 \mathrm{~g} / \mathrm{m}^{2}$ plus $20 \%$ solution of calcium superphosphate of $500 \mathrm{ml} / \mathrm{m}^{2}$ ater $8 \mathrm{~h}$. exposure time.

PRATT (1979) noted that physical and biological management restrictions on the use of manure on lands include pathogen transmission; crop quality; water and soil quality. And as management systems change, field research with the manure produced is needed to assess $\mathrm{N}$ availbility. Manure treated with disinfectants is controled by its effect on nutrients availability in addition to its nitrogen content. 


\section{EVALUATHON OF DISINEEECTANHS}

The objective of this study was to evaluate the effectiveness of some disinfectants applied to feedlot wastes and poultry litter experimentally contaminated with S.typhimurium, E.coli coryn. pyogenes and Śtaph. aureus as well as its biological value after disinfectants being applied. Moreover, the question is raised as to determine the bacteriocidal effectiveness of superphosphate compound in addition to its biologicl value.

\section{MATERIAL and METHODS}

\section{Bacteriocidal effectiveness :}

In this trial 15 samples of dirty floor containing manure were collected from each of conventional units of cattle, sheep and poultry inthe vicinity of Assiut. 30 $\mathrm{g}$ of each mixed sample of soil or litter were placed in $17 \mathrm{~cm} \emptyset$ Petridishes and all of it were sterilized by autoclaving. Strains of Staphylococcus aureus; Escherichia coli, Salmenella typhimurium and Corynebacterium pyogens were used as test organisms for evaluating the bacteriocidal action of disinfectants. 5 Petridishes of each soil sample were contaminated with each of the liquid culture media of microorganisms in an equivalent volumes. The organisms were supplied from Dept. of Microbiology, Fac. of Med., Assiut University.

Testing was porformed with $4 \%$ formalin (Containing $38 \%$ of formaldehyde gas), quick lime, fresh hydrated lime, chlorinated lime (containing $26 \%$ active chlorine) and commercial superphosphate compound applied at proportion of $0.5 \mathrm{~g} / 15 \mathrm{~cm}^{2}$ surface area of soil or litter. Effectiveness was determined from microbiological swabs after exposure time of $15,30,45,60$ minutes and then every hour up to 12 hours. Cultivation was carried out on MacCONKEY agar media for Salmonella and E.coli, while salt mannitol agar and tellurite blood agar media were used for Staph. and Coryn. pyogens respectively (CRUICKSHANK et al., 1980).

Biological value of feedlot wastes after disinfectants being applied :

Total nitrogen ( $T . N$ ), ammonium nitrogen $\left(\mathrm{NH}_{4}\right)$ and nitrate nitrogen ( $\mathrm{No}_{3}$ ) were determined according to PAGE et al. (1982). Soll $\mathrm{pH}$ was measured using glass electrod (JACKSON, 1958).

\section{RESULTS}

It was clear from Table (1) that the most bacteriocidal action within a shorter exposure time was obtained by quick lime (30 $\mathrm{min}$ ). Moreover, slaked lime killed Stapylococcus aureus in soiled wates after $45 \mathrm{~min}$. While $15-30 \mathrm{~min}$. for the other strains of bacteria. Also 4\% formalin killed Salmonella typhimurium and Coryn. pyogens in wastes within one hour exposure time while Staph. aureus and E.coli killed within 4 and 2 hours respectively. Low effectiveness was revealed with chlorinated lime, and superphosphate $(6-12$ h.).

The data presented in Table (2 and 3) showed that :

1- Poultry litter contining droppings have highest total nitrogen content value compared with feedlot wastes of sheep and cattle. The latter revealed the lowest total nitrogen value.

Assiut Vet.Med.J. Vol. 21, No. 42, 1989. 


\section{AdH. HAFEZ, et al.}

2- No change total N\% of the waste types was noticed when formalin or superphosphate were used compared with the control samples.

3- Superphosphate treatments gave a pronounced effect on keeping ammonia against loss. the highest value of $\mathrm{NH}_{4}$ were revealed after superphosphate treatment over control and disinfectants.

4- Regarding to $\mathrm{NO}_{3} \%$ of treated samples, no specific trend could be detected after the application of different compounds.

\section{DISCUSSION}

Disinfection as part of sanitation procedures protect the quality of the environment and permits the utlization of feedlot wastes for subseuent agriculture purposes. It is well established that incidence of latent infections increases when animals of homogenous populations are concentrated in confinement. A number of epidemiological reports have attestøad that transmission of enteric disease can occur when untreated wastes are used in cultivated lands (YEAGER, 1980). From the economic point of view, the daily exretion of wastes ranges from $3.6 \%$ of total live weight for sheep, $4.6 \%$ for beef cattle, $6.6 \%$ for laying hens, to $9.4 \%$ for dairy cattle (TAIGANIDES, 1977). In the hight of the present facts, the protection of agricultural environment from poullution by means of animal wastes is an urgent matter.

Investigations on the efficieny of tested compounds for bacteriocidal action as well as the biological value of wastes after such compounds being applied explained the following:

1- Chlorinated lime quickly looses its effectiveness as disinfectant in the presence of organic matter which protect the germs (Table 1). Moreover, it lowered the nitrogen content of waste types as well as highly increased its alkalinity which make it unsuitable for further use in agriculture (Tables, $2 \& 3$ ).

2- Lime, whether quick lime or slaked lime, although it revealed a good bacteriocidal action (Table 1) and its lack of noticable odour, it lowered the biological value of wastes through higher alkalinity and noticable decreae in total nitrogen content (Tables 2 \& 3). It could be concluded that lime treatment could be beneficial in acid soils of humid regions since $\mathrm{pH}$ value of Egyptian soils lies in the neutral to slightly alkaline range.

3- It was concluded from the study that formalin proved as a good disinfectant (Table 1) and also do not alter the total nitrogen content of wastes as well as its effectiveness, it could be added to formalin to lower $\mathrm{pH}$ and increase its biological value for agriculture purposes as well as a deodorant.

\section{REFERENCES}

Cruickshank, R.; Duguid, T.P.; Marmion, B.P. and Seain, R.H. (1980): "Medical microbiology". 12th Ed., Vol. 11, Churchill Livingstone and Robert Stevenson. Edinburgh, L.E. London.

Assiut Vet.Med.J. Vol. 21, No. 42, 1989. 


\section{EVALUATION OF DISINFECTANTS}

Dykstra, R.R. (1961): Animal sanitation and disease control. The Interstate Inc. Danville Illinois, USA.

Grinitsina, G.A. (1964): "Disinfection for Listeriosis". In: Probleny Veterinarnoi Sanitari Edited by N.F. Rostoutseva, 11: 134-139.

Ismail, A.A. (1967): A comparative study of the chemical disinfectants used in Egyptiat Veterinary Practice. M.D.Vet. Thesis Fac. of Vet. Med., Assiut University.

Jackson, M.L. (1958): Soil chemical analysis, Constable and Co., London.

Krasnoshchekov, V.A. (1962): Disinfection of piggeries infected with swine erysipelas: Aerosol method of disinfecting piggeries. Trudy Vses., Inst. Vet. Sanit. 20: 231-242

Page, A.L.t Miller, R.H. and Keeney, D.R. (1982): Mehtods of soil analysis. Part 2, American Soc. of Agron, Inc., Soll, Sci, Soc. of Amer. Inc. Madison, Wisconsin. USA.

Pratt, P.F. (1979): Management restrictions in soil application of manure. J. of Anim. Scl. $48(1):$ 1s4-14s.

Taignides, E.P. (1977): Animal wastes. Applied Science Publishers, LTD. London.

Taylor, J.C. (1971): Regulatory aspects of recycled livestock and poultry wastes. In: Livestock waste management and pollution abatement. pp. 291-292 ASAE.

Yeager, J. (1980): Risk to animal health from pathogens in municipal sludge. In: Sludge health risks of land application, Ed. R.C. Loehr, 173-199. Ann. Arbor, Mich: Ann. Arbor Science.

Yovchev, E. (1974): Disinfection for salmonella abortion in sheep. Academy of Science. 297-300. Sofia, Bulgaria. 
AdH. HAFEZ, et al.

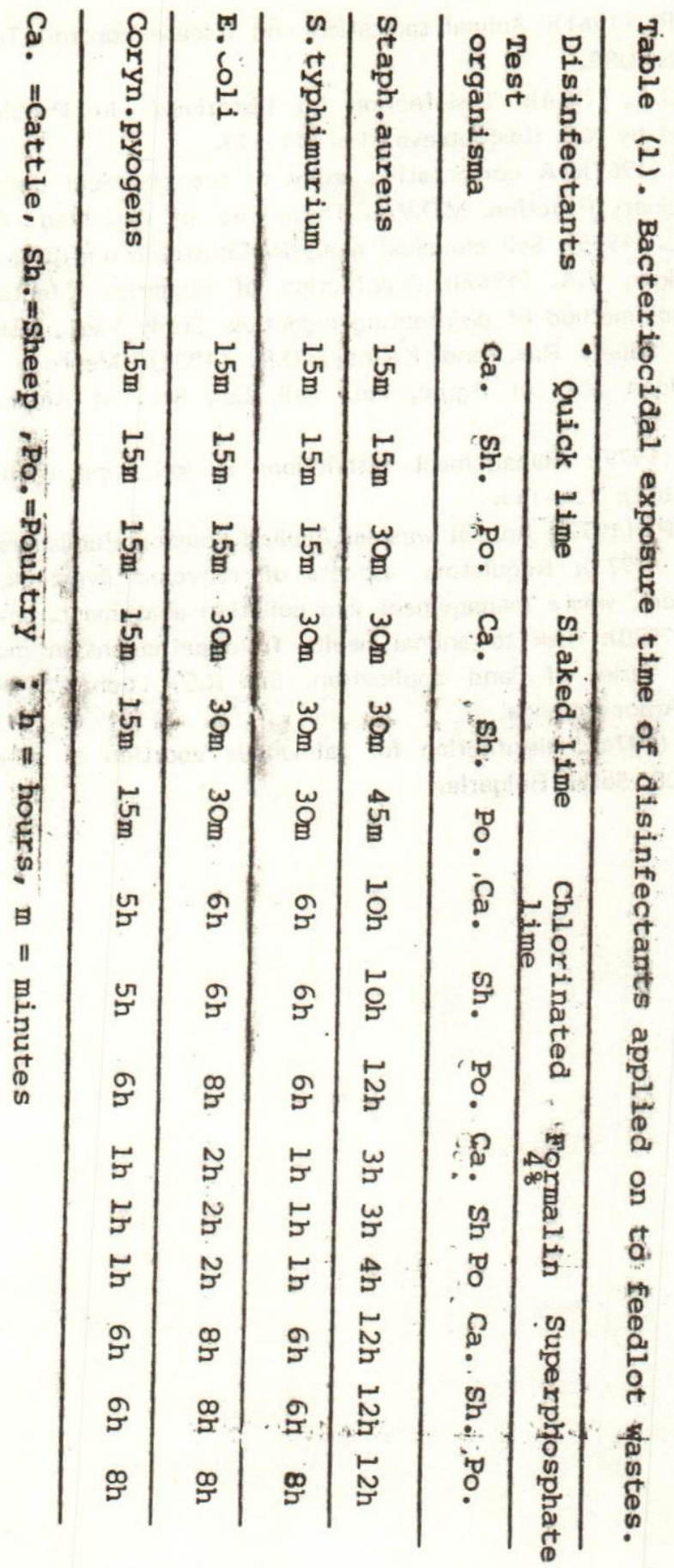


EVALUATION OF DISINFECTANTS

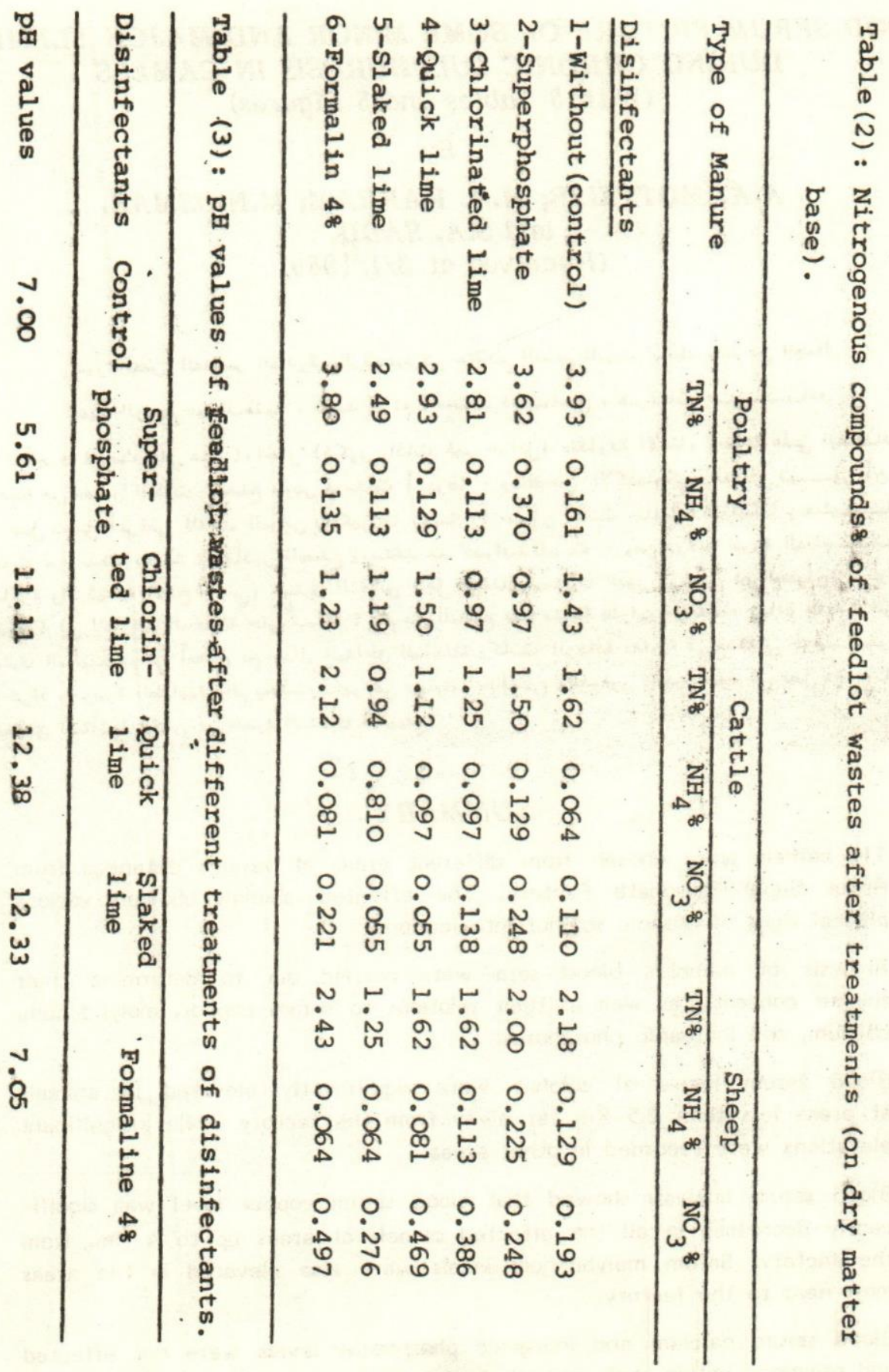

